\title{
The assessment of a municipal economic and social system's economic security
}

\author{
Pak Khe Sun ${ }^{1}$, Lubov Vorona-Slivinskaya ${ }^{2}$, Elena Voskresenskaya $^{2}$, Natalia Morozova $^{3}$ \\ ${ }^{1}$ St. Petersburg University of Management Technologies and Economics, Lermontovskiy pr., 44, St. \\ Petersburg, 190103, Russia \\ ${ }^{2}$ St. Petersburg University of the State Fire Service, Moskovsky Pr., 149, St. Petersburg, 196105, \\ Russia \\ ${ }^{3}$ St. Petersburg State Forest Technical University, Institutskiy per., 5, St. Petersburg, 194021, Russia
}

\begin{abstract}
The article is devoted to problems of the assessment of municipal economic and social system's economic security. The subjects of the research are municipal and urban districts of Leningrad region. We suggest that the system of specific indicators could be used for the description and assessment of an economic security of municipal districts. The indicators could be applied for the monitoring and setting the strategy of healthy social and economic development of the district by local authorities.
\end{abstract}

\section{Introduction}

The economic security of a community is one of the most essential factors of state stability and development in a domestic and international context [1]. For the local authorities it is vital to have tools which could be the basis for social and economic systems' economic security assessment. The issues of territories' economic security are extensively studied from the federal and regional points of view. However, the local aspects of the problem haven't been investigated in a detailed way up to the present time.

Municipal districts are very complicated social and economic systems. Simultaneously with sustainability to negative internal factors the systems need to be targeted to sustainable development. The main aim of such development, for which local authorities are responsible, is the raising of living standards [2]. Several experts, including E. Petrova [3], claim that social and economic development indicators are linked not only to the certain kinds of events or activity. They describe the local environment all in all, as a result of cumulative impact of different factors including factors that coming up during the event or program implementation. Some other famous scientists [7-10,15] contributed a lot for the state and municipal security development theories, included D. Ursul [4], J. Kirshner [6].

\section{Experimental section}


Local (municipal) security is a complicated notion which includes subsystems of economic, social, political and other security. An economic security is the key subsystem. It includes finance, fiscal, budget, manufacturing, social systems of lower level. Municipal economic security's demands are crucial basic expectation for a certain person, family, community and whole state [5]. Municipal management failure cause the economic security threat for locals and district consequently the system of indicators for assessment the level of economic security is crucial for local management.

We assume that it is important to include into the indicators system some elements that could objectively depict finance, fiscal, budget, manufacturing, social subsystems of municipal district. However, we could not find any reliable information concerning the objective threshold level of such indicators, although the different lists of them are well known and well studied. The diversity and discrepancy in the indicators evaluation, which we faced, lead to poor quality of the monitoring and analysis of local economy sustainability. At last we decided to use the traditional way for defining threshold level of economic security indicators - we took the critical (limit) level for each indicator. As a result, if the actual value of the indicator is more or equal to minimum that means weakness of local economic security. In a contrast, if the actual indicator value is more or equal to maximum we could conclude that the economic security is provided properly.

\section{Results section}

The indicators of official reports, including statistical statements, reflect the root aspects of local economic security. The crucial data for economic security assessment indicators system we took from the municipal statistics database of Russian Federal State Statistics Service. We suppose that it is enough to have $10 \mathrm{key}$ indicators to estimate the level of municipal economic security and municipal managerial effectiveness. The list of the indicators could be wider if we would have more reliable statistics data and more innovative assessment methodology [11-14].

The indicators of municipal social and economic system of Leningrad region are shown in the Tables 1 and 2 .

Table 1. The level of Leningrad region municipal economic and social system's economic security, 2015.

\begin{tabular}{|l|c|c|c|c|c|}
\hline $\begin{array}{c}\text { Municipal and } \\
\text { urban } \\
\text { districts }\end{array}$ & $\begin{array}{c}\text { Companies' } \\
\text { turnover per } \\
\text { person, } \\
\text { ths rub. }\end{array}$ & $\begin{array}{c}\text { Investments } \\
\text { to fixed assets } \\
\text { per person, } \\
\text { ths rub. }\end{array}$ & $\begin{array}{c}\text { Retail } \\
\text { turnover } \\
\text { per person, } \\
\text { ths rub. }\end{array}$ & $\begin{array}{c}\text { Commercial } \\
\text { services per } \\
\text { person, } \\
\text { ths rub. }\end{array}$ & $\begin{array}{c}\text { Balanced } \\
\text { financial } \\
\text { result per } \\
\text { person, } \\
\text { ths rub. }\end{array}$ \\
\hline $\begin{array}{l}\text { Leningrad region } \\
\text { (average value) }\end{array}$ & 903.7 & 101 & 99.7 & 16.9 & 280.3 \\
\hline Threshold level & $86.5-2993.6$ & $10-381$ & $18.5-$ & $1,1-25$ & $(-) 592.7-$ \\
\hline Boksitogorsky & 444.7 & 27 & 26.1 & 5.1 & 274.7 \\
\hline Volosovsky & 145.1 & 23 & 24.3 & 8.0 & 32.4 \\
\hline Volkhovsky & 423.8 & 32 & 37.5 & 11.1 & 67.1 \\
\hline Vsevolozhsky & 1028.8 & 68 & 179.7 & 7.6 & 550.6 \\
\hline Vyborgsky & 542.3 & 35 & 53.0 & 15.9 & 627.5 \\
\hline Gatchinsky & 344.8 & 31 & 53.0 & 13.5 & 378.2 \\
\hline Kingiseppsky & 2993.6 & 132 & 83.0 & 16.1 & 1421.6 \\
\hline Kirishsky & 1654.9 & 337 & 138.6 & 20.3 & -592.7 \\
\hline Kirovkky & 749.3 & 51 & 44.0 & 25.0 & 143.6 \\
\hline Lodeynopolsky & 86.5 & 26 & 29.0 & 1.1 & 0.9 \\
\hline
\end{tabular}




\begin{tabular}{|l|c|c|c|c|c|}
\hline Lomonosovsky & 2623.6 & 94 & 72.7 & 6.6 & 3448.8 \\
\hline Luzhsky & 684.4 & 25 & 34.4 & 7.7 & 128.0 \\
\hline Podporozhsky & 260.3 & 10 & 25.6 & 4.6 & 156.4 \\
\hline Priozersky & 144.8 & 37 & 29.6 & 5.8 & 6.2 \\
\hline Slantsevsky & 383.4 & 23 & 18.5 & 12.2 & -460.7 \\
\hline Tikhvinsky & 643.4 & 136 & 32.7 & 17.5 & -164.6 \\
\hline Tosnensky & 418.9 & 50 & 57.4 & 13.8 & 99.4 \\
\hline $\begin{array}{l}\text { Sosnovoborgsk } \\
\text { urban district }\end{array}$ & 1190.5 & 381 & 168.0 & 21.3 & -2.6 \\
\hline
\end{tabular}

As the table's data show, Lodeynopolsky district belongs to those whose conditions are equal the threshold level of economic security (based on «Companies' turnover» index 86.5 ths rub per person). Very close to this limit are Volosovo, Volkhov, Vyborg, Gatchina, Kirov, Luga, Priozersk and Slantsevsky, Tosnensky, Podporozhsky districts. Their index lower than average for region (903.7 ths rub per person). The decline trend in their investment activity is the crucial reason for this scenario. This trend is not prevailing for all districts. Conversely, Kingiseppsky district has absolutely appropriate level - 2993.6 ths rub per person. In addition, very close to it are Vsevolozhsk, Kirishi and Lomonosov districts.

The highest level if we speak about index "Investments to fixed assets" belongs to Sosnovoborgsk urban district (381 ths rub per person is appropriate level). Close to it is Kirishsky district (337 ths rub per person). Tikhvin and Kingisepp municipal districts took out more outstanding index level. Others districts having indexes lower than average (more than $5-10$ times) could be described as have fallen behind. They are very close to the threshold level - 10 ths rub per person (as Podporozsky district has). Loss of investments to extracting companies, machining productions sphere, logging companies is the reason for Podprorzsky district declining trend.

The appropriate level of "Retail turnover per person" index belong to Vsevolozsky district (179.9 ths per person). Quite good results are shown by Kirishsky district (138.6 ths rub per person). Other participants of targeted group have indexes lower than average for region. The territory of Slantsevsky district demonstrates the critical level of economic security (18.5 ths rub per person). Bogsitogorsky, Volosovo, Lodeynoye Pole, Podporozhsky and Priozersk districts behave likely as the last one. Deterrents to growth of retail activity from our point of view are follows factors: costly rent payments, non transparent and overrated payments for grid connection, difficulties for small and micro business development (administrative barriers, corruption level, costly borrowings, etc.). However, nowadays the small and micro business companies are those who deal with retail sphere at territories that have not been occupied yet by retail groups.

As is clear from the results of investigation the best level "Commercial services" index belongs to Kirovsky district ( 25 ths rub per person). As close to it as possible are situated Kirishi, Tikhvin districts and the Sonovoborgsky city district. Their indexes are higher than region's average level (16.9 ths rub. per person). Others territories occupies quite depressive zone - less than average and sometimes close to limit (1.1 ths rub per person). The reason is that development of territories' commercial servicing activity is not meeting the expectation.

Lomonosovsky district has highest level of "Balanced financial result" parameter. It equal to the appropriate value 3448.8 ths rub per person. The second-ranked are Kingisepp, Vsevolozhsk, Vyborg, Gatchina districts. Their indexes are higher than average (280.3 ths rub per person). It is clear that the threshold index (-592.7 ths rub per person) belongs to Kirishsky district. We have to identify the negative scenario, evidence of which was obtained during the investigation concerning Slantsevsky, Tikhvin districts and the 
Sonovoborgsky urban district. A lot of unprofitable companies of manufacturing industry and construction are located at those territories.

Table 2 data could help to highlight some more details concerning local economic and social systems' features.

Table 2. The level of Leningrad region municipal economic and social system's economic security, 2015.

\begin{tabular}{|l|c|c|c|c|c|}
\hline $\begin{array}{c}\text { Municipal and } \\
\text { urban } \\
\text { districts }\end{array}$ & $\begin{array}{c}\text { Fiscal } \\
\text { capacity } \\
\text { per } \\
\text { person, } \\
\text { ths rub }\end{array}$ & $\begin{array}{c}\text { Growth rate } \\
\text { of local } \\
\text { economy's } \\
\text { employees' } \\
\text { average } \\
\text { number, \% }\end{array}$ & $\begin{array}{c}\text { Average } \\
\text { monthly } \\
\text { nominal } \\
\text { accrued wages, } \\
\text { rub }\end{array}$ & $\begin{array}{c}\text { Total floor area } \\
\text { of residential } \\
\text { premises has } \\
\text { become } \\
\text { available per } \\
\text { 1000 persons, } \\
\text { sq.m. }\end{array}$ & $\begin{array}{c}\text { Share of } \\
\text { innovative } \\
\text { municipal } \\
\text { educational } \\
\text { institutions, } \\
\%\end{array}$ \\
\hline $\begin{array}{l}\text { Leningrad } \\
\text { region (average } \\
\text { value) }\end{array}$ & 29.9 & 101.3 & 38730.5 & 1312.7 & \\
\hline Threshold level & $21-43.9$ & $97.8-105.9$ & $30163.6-$ & $70.9-4557.5$ & $90-100$ \\
\hline Boksitogorsky & 34.7 & 98.9 & 31340.5 & 157.0 & 92.7 \\
\hline Volosovsky & 32.6 & 103.4 & 30914.3 & 487.4 & 100 \\
\hline Volkhovsky & 28.4 & 97.8 & 30875.3 & 386.4 & 100.0 \\
\hline Vsevolozhsky & 24.4 & 101.7 & 41620.6 & 4557.5 & 97.5 \\
\hline Vyborgsky & 24.0 & 100.7 & 38347.4 & 564.7 & 95.0 \\
\hline Gatchinsky & 21.0 & 98.2 & 34278.9 & 738.3 & 93.7 \\
\hline Kingiseppsky & 33.7 & 98.7 & 43796.9 & 594.7 & 94.1 \\
\hline Kirishsky & 34.4 & 102.7 & 43374.4 & 618.6 & 100.0 \\
\hline Kirovsky & 26.9 & 101.7 & 40092.9 & 542.9 & 94.0 \\
\hline Lodeynopolsky & 36.1 & 104.9 & 26543.2 & 371.2 & 100.0 \\
\hline Lomonosovsky & 25.7 & 101.3 & 53283.2 & 2810.3 & 99.6 \\
\hline Luzhsky & 27.9 & 99.3 & 29562.5 & 380.3 & 90.0 \\
\hline Podporozhsky & 43.9 & 98.3 & 30163.6 & 366.0 & 100.0 \\
\hline Priozersky & 21.3 & 103.9 & 27865.0 & 904.6 & 95.0 \\
\hline Slantsevsky & 37.8 & 102.3 & 28323.8 & 70.9 & 90.0 \\
\hline Tikhvinsky & 29.1 & 101.3 & 33753.1 & 113.3 & 95.6 \\
\hline Tosnensky & 21.2 & 105.9 & 35025.4 & 802.9 & 97.0 \\
\hline $\begin{array}{l}\text { Sosnovoborsky } \\
\text { urban districts }\end{array}$ & 35.1 & 101.8 & 53854.5 & 971.7 & 100.0 \\
\hline & & & & & \\
\hline Disoriting & & & & & \\
\hline
\end{tabular}

Disparities in the municipal authorities' funds level ("Fiscal capacity" parameter) depend on local government's tax and non tax incomes and inter-budgetary transfers' level. Actually the most appropriate local government funds' level we found in a Podporozhsky municipal district (43.9 ths rub per person). A little bit less amount of funds per person have Boksitogorsk, Volosovo, Lodeynoye Pole, Slantsevsky, Kingisepp, Kirishi districts and the Sonovoborsky urban district. The level of their funds is more than average region level - 29.9 ths rub per person. In the studied period (2015) The Finance Committee of the Leningrad region provided a financial assistance for last three districts mentioned above as for those that succeeded a lot in tax collection policy. The worst results has Gatchinsky district - about 21 ths rub per person. Not far better index has Tosnensky and Priozersky districts - less than regional average level. Finally, it is worth being mentioned that other local authorities' funds level is less than regional average.

Growth rate of local economy's employees' average number reflects the territory employment level. The threshold value of economic security concerning this parameter belongs to Volkhovsky district. Demand for labour outpaces labour's proposal in this 
territory more than 1.4 times. Gatchinsky, Kingiseppsky, Luzsky and Podporozhsky districts tend to be similar. Their employment level is less than regional average. The best employment index belong to Tosnensky municipal district $-105.5 \%$. All other territories, excluding Viborgsky district, have parameters higher than region's average.

The highest monthly nominal accrued wages is at Sosnovoborsky urban district. Local employees that take part in a research and development sphere earn about $70843 \mathrm{rub}$, in electric power engineering, gas fuel handling facilities and water supply sectors - about 68300 rub, in construction industry - about 59789 rub. In the Lomonosovsky, Vsevolozhsky, Kingiseppsky, Kirishsky, Kirovsky districts wages are quite high and approximately equal or around to the regional average level (38730.5 rub). The lowest salary is paid in the Lodeynopolsky district -26543 rub.

The residential construction parameter shows that the best is Vsevolozhsky district about 4557.5 sq.m. per 1000 person became available annually. The next place accordingly belongs to Lomonosovsky district -2810 sq.m. The distinctive advantage of the last mentioned above is a rapid growth of low-rise residential construction situated close to the city. All other territories haven't reached the average index (1312.7 sq.m. per 1000 persons). The lowest index describes Slantsevsky district.

Indicator "Share of innovative municipal educational institutions" we used to investigate the quality of teaching process in districts. Here we suggest that "innovative" institutions include those that perform all contemporary methodological and technical requirements for educational institutions. All educational institutions of Volosovsky, Volkhovsky, Podporozhsky municipal districts and Sosnovoborsky urban district in 2015 (as surely as in 2013 and 2014) were considered as "innovative". In 2015 the same situation we witnessed in Lodeynopolsky and Kirishsky territories (although only accordingly 91\% and $94 \%$ in 2014). 90\% of education institutions of Luzhsky and Slantsevsky districts reached the target.

To sum up, the most favorable district in view of economic security is Vsevolozhsky. It has 2 parameters that occupy appropriate zone. They are retail turnover per person and construction activity (total floor area of residential premises has become available per 1000 persons). Indexes "Companies' turnover per person", "Balanced financial result per person", "Growth rate of local economy's employees' average number", “Average monthly nominal accrued wages" and "Total floor area of residential premises has become available per 1000 persons" are higher than Leningrad regional average.

Among the districts with threshold economic security level we could indicate Lodeynopolsky and Slantsevsky territories. Lodeynopolsky district shows 2 indicators very closed to limits ("Commercial services per person" and "Average monthly nominal accrued wages"). In addition other it's characteristics are lower that average level, excluding "Fiscal capacity" and "Growth rate of local economy's employees' average number".

In the Slantsevsky zone next parameters are critical: "Retail turnover per person", "Total floor area of residential premises has become available per 1000 persons", "Share of innovative municipal educational institutions". Other indexes are lower than average level, excluding "Fiscal capacity" and "Growth rate of local economy's employees' average number". As a result the level of economic and social attractiveness of Lodeynopolsky and Slantsevsky districts is unacceptably weak.

\section{Discussion section}

As the result of the analysis we would like to highlight some points. Firstly, only one municipal district has the highest number of positive parameters. Secondly, indexes of two districts are close to the critical level. Finally, majority of districts have slightly more number of positive indicators compared with number of critical level indicators. 


\section{Conclusions}

On the basis of actual analysis we could conclude that it is crucial for majority municipal government to enhance the efforts targeted to improving local social and economic systems' security level. The systematic monitoring of economic security indicators, which reflect the social and economic trends in the municipal district, is the key instrument for territory development strategy making and everyday municipal managerial efforts. It is worth creating the more detailed system of municipal economic and social security's parameters. It's obvious that the system of municipal economic and social security's indicators used in this research is not as full as it could be or could be expected. However, we would like to state that our approach is effective enough and could be recommended for municipal management system as a basis for the social and economic district's development monitoring and management.

\section{References}

1. Y.S. Butakova, Actual problems of economic science 6, 2 (2009)

2. V.B. Zotov, A municipal administration system (Moscow, 2006)

3. E. Petrova, Actual problems of economic science, 35 (2013)

4. A. D. Ursul, Journal of Eurasian security, 1 (2001)

5. J. Kirshner, Review of International Political Economy 5, 1 (1998)

6. T.L. Silin, Basic Research 9, 5 (2009)

7. S.S. Reshiev, Regional economy: theory and practice, 4 (2010)

8. D.A. Gulin, Regional economy: theory and practice, 12 (2013)

9. S.I. Krylov, The economic analysis: theory and practice, 15 (2013)

10. L.G. Vorona-Slivinskaya, M.V. Lobanov, Problems of risk management in the technosphere, 12(4) (2009)

11. Economy of municipal districts and urban districts of the Leningrad Region in January - December 2015 (2016)

12. Reports on budget execution of municipalities and municipal districts of the Leningrad Region for 2015 (2016)

13. Information on the socio-economic development of municipalities and municipal districts of the Leningrad region in 2015 (2016)

14. URL: http://petrostat.gks.ru/wps/wcm/connect/rosstat_ts/petrostat/ru/municipal_statistics

15. L.G. Slivinskaya, Safe and sustainable development of the region (Publ.h. of SPb SUFS of EMERCOM, SPb, 2016) 